\title{
Assessment of Shoreline and Associated Landuse/Land cover Changes along Part of Lagos Coastline, Nigeria
}

\author{
Francis O. Akinluyi, Abiodun O. Adebola*, Adebowale A. Adeseko \\ Department of Remote Sensing and GIS, Federal University of Technology Akure, Ondo State, Nigeria \\ * corresponding author: collinola@gmail.com
}

Received: $2^{\text {ed }}$ February, 2018

Accepted: $19^{\text {th }}$ April, 2018

\begin{abstract}
The city of Lagos, Nigeria has undergone rapid increase in population due to economic and commercial activities. As a result of this, there has been a persistent change in Land use/Land cover (LULC) of the city and shoreline through the years. This observation necessitated the use of multi-temporal satellite data to characterize shoreline changes between 1984 and 2016. Therefore, the study attempts to determine the shoreline change during the study period and the coastal land use and land cover (LULC) of the study area. Satellite data was acquired andsubjected to some image processing techniques such as image enhancement, supervised classification, and shoreline extraction. The digital shoreline analysis system (DSAS) in ArcGIS environment was utilized to cast transects and calculate statistical parameters for the shoreline and spatial data used was Landsat TM, ETM and OLI for the years 1984, 1990, 2000, 2004 and 2016 respectively. The results indicate that LULC changes in builtup areas increases rapidly during the years (1984-2015) from $12.2-36.2 \%$, water bodies increased from (19841990-2000) from $52 \%, 54 \%, 52 \%$ and reduces to $47.4 \%$ in the year 2015 while vegetation cover reduces drastically through the year range from $36 \%, 33 \%, 29 \%, 24 \%$ and $16 \%$. A total of 1034 transects were generated with $100 \mathrm{~m}$ spacing and the average rate of change was calculated for the 32 year period (1984-2016). The linear regression rate (LRR) shoreline result shows a mean of $-0.59 \mathrm{~m} /$ year where $73.1 \%$ of transect fall under erosion and $61.8 \%$ accretion respectively. The end point rate (EPR) and net shoreline movement (NSM) analysis revealed mean shoreline change of $-0.57 \mathrm{~m} /$ year and $-18.1 \mathrm{~m} /$ period respectively from $1984-2016$. The EPR and NSM results both revealed that 231 transect or $22.3 \%$ experienced erosion, and 805 transect or $77.9 \%$ with accretion. It was observed that significant accretion rate recorded along most sections of the shorelines is attributed to beach nourishment activities.
\end{abstract}

Key words: Shoreline change, Landuse/Land cover, Accretion, Erosion and Lagos

\section{Introduction}

Coastal erosion is a global problem affecting almost every country around the world having a coastline. This problem is expected to accelerate in the future due to the global warming phenomenon (Appeaning, et al., 2008), which most likely will cause a sea-level rise and increase the number of storm events across the globe (Boak\& Turner, 2005). Coastal shorelines, the interface between land and sea (Bird, 1967; Dolan et al., 1980) change variably in response to one or more factors, which may be morphological, climatological or geological in nature (Carter and Woodroffe, 1994 and Pidwirny, 2006b).Shoreline is referred to as the interface between the land and the sea (WIOMSA, 2010) and the immediate position of the land-water line at one instant in time (Boak and Turner, 2005). However, Shoreline change is the uncontrollable result of coastal erosion or accretion, the effect of near shore currents (Pidwirny, 2006b). Shoreline change depicts the way in which the position of the 
shoreline moves with time (WIOMSA, 2010). It is easy to define but difficult to capture since it is always changing. Nevertheless, because of the active nature of water bodies and the coastal land, the shoreline is constantly changing (Paterson et al, 2010). The change in shoreline is mainly associated with waves, tides, winds, periodic storms, sea-level change, and the geomorphic processes of erosion and accretion and human activities (Carter and Woodroffe, 1994).As a consequence, coastal and estuarine shorelines can progress through significant phases of erosion and/or deposition during time-scales of years to decades. Quantitative analysis of shoreline changes at historic timescales is very important for understanding processes which drive coastal erosion and accretion. This enables the computation of regional sediment budgets, identification of hazard zones or even as a basis for morphodynamics modeling. Likewise, the dynamic processes of shoreline erosion and accretion are often attributed to hydrodynamic forces (e.g. river cycles, sea level rise), geomorphological changes (e.g. spit development), anthropogenic actions (e.g. port development, tidal power generation, construction, dredging) or other sudden forces (e.g. storm events, earthquakes and tsunamis, rapid seismic events).

In addition, the constant shoreline variation examination facilitates recognizing the nature and processes that caused these changes in any area to assess the human impact and to plan management strategies.

Remote sensing data and geographic information systems (GIS) could be used effectively to observe the changes along the coastal zone, including shoreline with reasonable accuracy (Berlanga-Robles and Ruiz-Luna, 2002). Remote sensing helps to replace the conservative survey data by its rhythmic and cost effectiveness. The key physical parameters that need to be understood in order to identify coastal erosion problems in the coastal zones are; Coastal geomorphology, Wind, Waves, Tides, Vegetation. Equally, significant human activities that must be considered over the range of spatial and time scales are: activities along the coast, activities within river catchments/watersheds, onshore and offshore activities (Ajayi and Adetayo, 1982). Furthermore, the accurate demarcation and monitoring of shoreline (seasonal, shortterm, and long-term) are necessary for understanding the various coastal processes. The advent of geographic information systems (GIS) and image processing softwares have offered possible techniques such as image processing and quantitative analysis, which to a reasonable degree of accuracy has made the monitoring of any shoreline changes due to erosion and/or accretion become practically possible.

Several studies pointed out that two main factors can be responsible for change in the shoreline, these are; human activities along the shore or natural processes (Richmond, 1997, Keqizhang et al., 2004, Boak and Turner, 2005, Hanslaow, D.J., 2007, Paterson et al, 2010,). An example of natural process can be sea level rise (SLR), change from storms and climate (Keqizhang et al., 2004) extreme weather events, including an increase in the intensity and frequency of waves on the shoreline face and beaches (Pearson et al., 2005). Williams and Gutierrez (2009) asserted that sea-level rise is one of the most important impacts for shoreline change which causes variations in waves, currents and sediment availability in most US coastal areas. Shoreline can also move landwards through the process of erosion or seawards by sediment accretion (WIOMSA, 2010). Shoreline change can also be used as a good indicator of possible coastal erosion and the best indicator for describing coastal erosion is the shoreline retreat rate (Boak and Turner, 2005)Many beaches around the world are subject to problems associated with beach erosion and recession (Hanslaow, D.J., 2007). Paterson et al, (2010) describe shoreline erosion as the group of natural processes including; weathering, dissolution, abrasion, erosion, and 
transportation, by which material is worn away from the earth's surface. In Kenya, Hoorweg and Muthiga (2009), reported that costal environment influenced by naturally occurring process such as erosion and sedimentation carried by Sabaki River. In addition to these natural processes, human action to control and mitigate erosion and maintain navigation channels can change the shoreline (Williams and Gutierrez, 2009). According to Richmond (1997), human actions such as the destruction of mangrove forests, sea grass beds, and coral reefs caused by tourism development can increase the exposure of the coast to wave actions which leads to erosion. In Kenya for example, a study by Kairu and Nyandwi, (2000) revealedthat in the last three decades, rapid development in the tourism industry has taken place on the beaches which have experienced increasing coastal erosion problems. Another study along the Kenyan coast by Government of Kenya, (2010a) indicated that in the built up areas, erosion in some cases has been exacerbated by humaninterference with the construction of seawalls. Sea walls increase reflected wave energy, leading to erosion and flattening of the adjoining beach, an example of the effect of sea walls can be seen at Mtwapa in Kenya, where walls have been built to protect shoreline properties (Kairu and Nyandwi, 2000).

According to Moore et al., (2006), several coastal areas are heavily populated and have been continuously changing hence; shoreline change analysis research has become a common goal of most coastal management plans. Furthermore, shoreline change analysis has become a suitable tool to understand temporal and spatial trends of beach erosion and accretion triggered by natural and human impacts (Limber et al., 2007). Therefore, understanding the process causing shoreline change and quantifying the shoreline change rate is crucial for better coastal area management. This study focused on utilizing multi-temporal satellite data to characterize shoreline changes from 1984 to 2015. By this means, measuring the rate of shoreline change and define the drivers of shoreline erosion and accretion in that period alongthe Lagos city coastline (Fig. 1) and also, determine the coastal land use and land cover of the study area.

\section{Study area}

Lagos state is located in the southwestern part of Nigeria and it is bounded to the west by the republic of Benin and to the north and east by Ogun state with the Atlantic Ocean providing a coast line in the south. Its geographic location lies between Latitudes $06^{\circ} 23^{\prime} 23.13^{\prime \prime} \mathrm{N}$, $06^{\circ} 23^{\prime} 55.7^{\prime \prime} \mathrm{N}$ and Longitudes03 $2^{\circ}$ '46.617' $\mathrm{\prime}$, $04^{\circ} 5^{\prime} 54.192$ ' E covering an area of $3907.968 \mathrm{~m}^{2}$ (Fig. 1).Lagos has a total of 3,577 square kilometer; where 787 square kilometers is made up of lagoons and creeks including Lagos lagoon, Lagos harbor, Ebute-metta creeks, Porto-Novo creek, new carnal, Badagry creek, five cowrie creek, Kuramo waters, and light house creek. Lagos is a very low-land state relatively flat in topography, near the coast (Atlantic Ocean) and is served by many rivers as well as lagoon. The dominant vegetation of the state is swamp forest consisting of the freshwater and mangrove swamp forest both of which makes the environment a wetland region. The climate of the state is divided into two climatic seasons; dry (November - March) and wet: (April-October). Annual rainfall ranges from $1524 \mathrm{~mm}$ beach erosion, $2031 \mathrm{~mm}$ in the western half of the state to $2032 \mathrm{~mm}$. The recent coastal deposits occur widely in Lagos state. Similarly, tertiary beds from the Benin Formation stretch from Calabarin the East through Lagos to the borders of Benin republic in the west. Lagos state is endowed with very little arable land. Altogether, four soil groups are identifiable. On the western half of the coastal margin, juvenile soils on recent windborne sands occur. The rest of second group in the coastal area towards the east is covered also by juvenile soils on fluvio-marine 


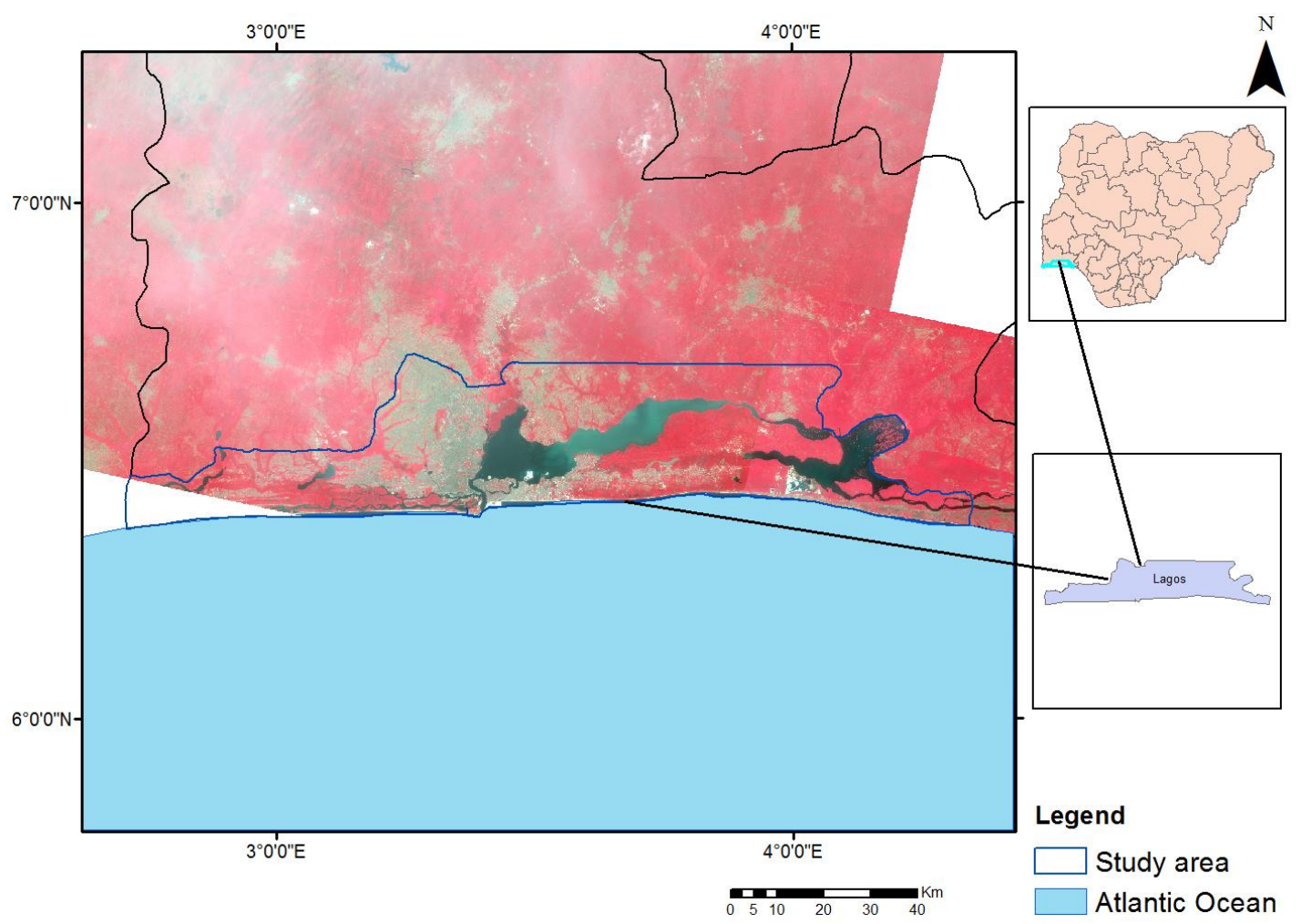

Fig.1. Location of study area.

alluvium (mangrove swamp). Thirdly, a narrow and rather discontinuous band of mineral and/or organic hydromorphic soils occur in the middle and north-eastern sections of the state. The fourth group occurs in two rather tiny and discontinuous patches along the northern limits of the state, consisting dominantly of red Ferrallitic soils on loose sandy sediments.

\section{Data sources and Methodology}

The sources of shoreline data are Landsat satellite images of the study area. They were acquired for five different epochs for 1984, 1990, 2000, 2004 and 2016 respectively. They were obtained through the U.S. Geological Survey Earth Resources Observation and Science Center (EROS) website http://earthexplorer.usgs.gov/. The remote sensing and Geographic Information System (GIS) software package, Erdas Imagine 9.2 was used for the preprocessing of the satellite data. The software was used specifically for atmospheric and geometric corrections. The
ArcGis 10.2 (ArcMap 10.2) was employed for different image processing techniques which includes; Image Enhancement for better visualization and delineation of shoreline, Image Classification and Shoreline Extraction and.The Landsat imageries for the study area were subjected to classification zones. Visual image interpretation was utilized to classify the images into different land use categories. In order to classify the rectified images, four classes were basically delineated in the images and they are built up, water body, vegetation and bare surface.

\section{Shoreline data analysis}

The shoreline extraction and analysis from the Landsat imagery was performed using ArcGIS 10.2 software. The shoreline change rate measurement followed the approach used by Hanslow, 2007, and Thieler et al., 2009 which includes digitizing a shoreline on georeferenced images and quantifying rates of shoreline change. A geo-database was created 
in ArcGIS for the digitized shoreline positions which comprised; year, ID, shape and uncertainty. The historical change was analyzed using Digital Shoreline Analysis System (DSASv4.3). DSAS computes rate of change statistics from multiple historic shoreline positions residing in a GIS (Thieler et al., 2009). DSAS in ArcGIS environment was utilized to cast transects and calculates statistical parameters for the shoreline. The area under study covers about $103.63 \mathrm{~km}$ and was digitized between 1984 and 2016 Landsat satellite images. Hypothetical baseline was constructed offshore and parallel to the general orientation of Lagos shoreline. This was done in order to assess spatial and temporal movement trend of the shoreline positions. In this study, three (3) statistical methods of End point rate, (EPR), Net shoreline movement, (NSM) and linear regression rate (LRR) were used to calculate the rates of change along Lagos shorelines. The EPR method is calculated by dividing the distance of shoreline movement by the time elapsed between the oldest and the most recent shoreline (Thieler et al., 2009)while LRR is the result of estimating the average rate of change using a number of shoreline positions overtime, with the change statistics of fitting a leastsquared regression line to all shoreline points of each transect. The LRR is the slope of the line. Therefore, LRR was used to analyze the long term Lagos shoreline change (from 1984-2016). The NSM calculates the distance between the oldest and youngest shorelines for each transect cast. The data uncertainty was $\pm 6 \mathrm{~m}$ and confidence interval was $90 \%$ determined as a weighted linear rate parameter.

\section{Results and discussion}

\section{Land use/ Land cover analysis}

The results through the histogram chat (Fig. 2) showed the area covered by each land usecategories for the studied years from 1984 to 2015. However, calculated values showed the changes that have occurred and average rate of change for each of the land use categories from 1984-1990, 1990-2000, 2000-2004 and 20042015(Fig. 3). A negative and positive value indicates decrease and increase respectively. The image classification map of the multitemporal imageries was classified into four classes of land use and land cover (Fig. 4) but the focus here is on three classes, and these were named as water body, built up, and vegetation (Table 1).

The buildup area wasobserved to have experienced a gradual increase from 1984-2014 ranging from $12.704 \%$ to $36.283 \%$ (Fig. 2). These values represent $0.649 \%$ to $13.464 \%$ increase in that period (Fig. 3). Conversely, it was evident that, there has been an alarming decrease in the vegetation cover from $34.069 \%$ in 1984 to $16.261 \%$ in 2016 . These values represent a decrease in the rate of change from $-2.28 \%$ to $-7.81 \%$. Consequently, the decrease in vegetation (Mangroves and Coconut trees) from 1984 to 2016 is believed to be due to rapid urbanization and industrialization along the coast line. These anthropogenic activities had limited entering of high tides and backwaters on to the main land. The water body seems to have increased relatively from $1984(51.227 \%)$ to $1990(53.867 \%)$ and a decrease to $52.704 \%$ in

Tab.1. Land use/cover classification

\begin{tabular}{ccccccc}
\hline \multirow{2}{*}{ S/N } & Land use & 1984 & 1990 & 2000 & 2004 & 2015 \\
\hline 1 & Built-Ups & 12.704 & 13.353 & 17.830 & 22.816 & 36.283 \\
2 & Vegetation Cover & 34.069 & 32.780 & 29.466 & 24.071 & 16.261 \\
3 & Water body & 51.227 & 53.867 & 52.70 & 58.127 & 47.456 \\
\hline
\end{tabular}




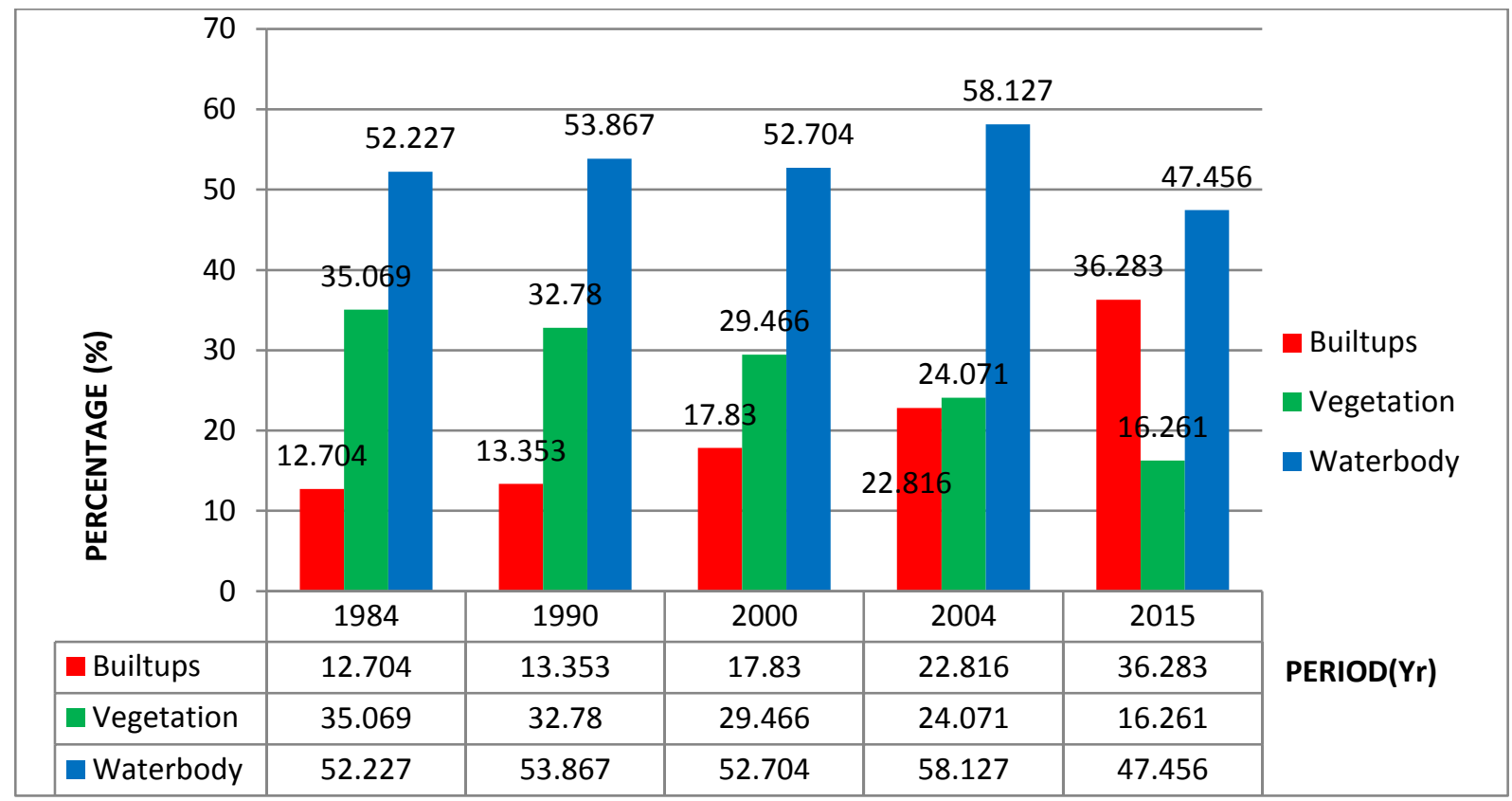

Fig.2. Land use/cover category

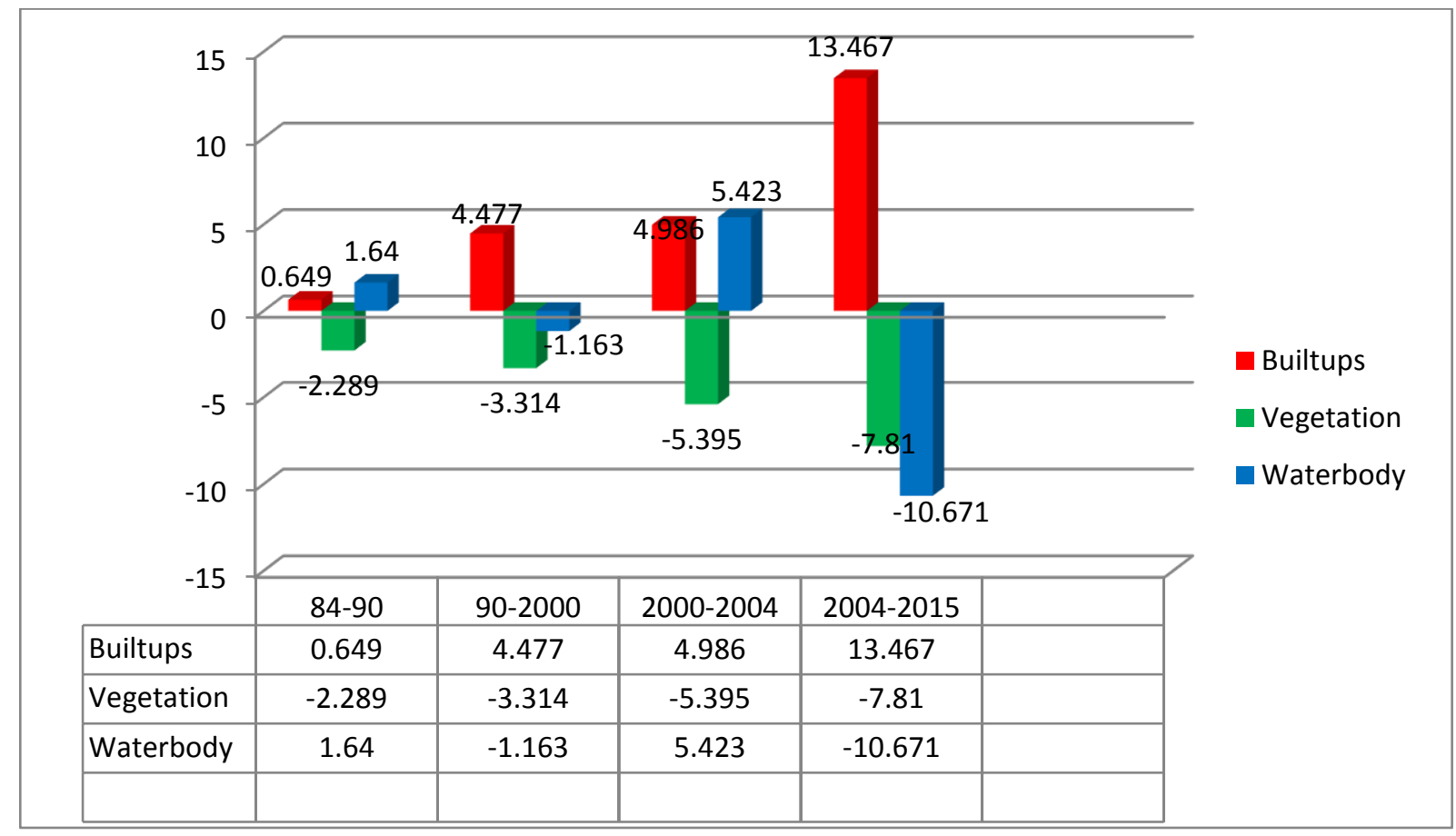

Fig.2. Land use/cover clasification

2000. This may be due to periodic flooding that is experienced in the area. Likewise, the water body increased all time high to $58.127 \%$ in 2004, possibly as a result of sea level rise (SLR). It was observed that by 2015 , the water body have decreased noticeably to $47.456 \%$ (Table 1). This may be attributed to anthropogenic activities (Reclamation process) that are rampant in the area.

\section{Shoreline Changes}

A total of 1034 transects were generated with $100 \mathrm{~m}$ spacing and the average rate of change 
was calculated from 1984-2016 (Fig.5). The rates of shoreline change along the Lagos city coastline is presented in Table 2. Positive values of EPR and LRR represent a shoreline movement towards the sea (accretion rate) and negative values represents a shoreline movement inland (erosion rate). The total length of the extracted shoreline of 1984
Landsat TM image is $64003.58 \mathrm{~m}$, for year 1990 is $71884.87 \mathrm{~m}$, for year 2000 is $75050.95 \mathrm{~m}$, and for 2016 is $75522.84 \mathrm{~m}$. The shorelines are represented with different colors. A closer look at the digitized shorelines show that there is a remarkable change in the shape of the shoreline over time as indicated in figures $6 \mathrm{a}$ and $6 \mathrm{~b}$.
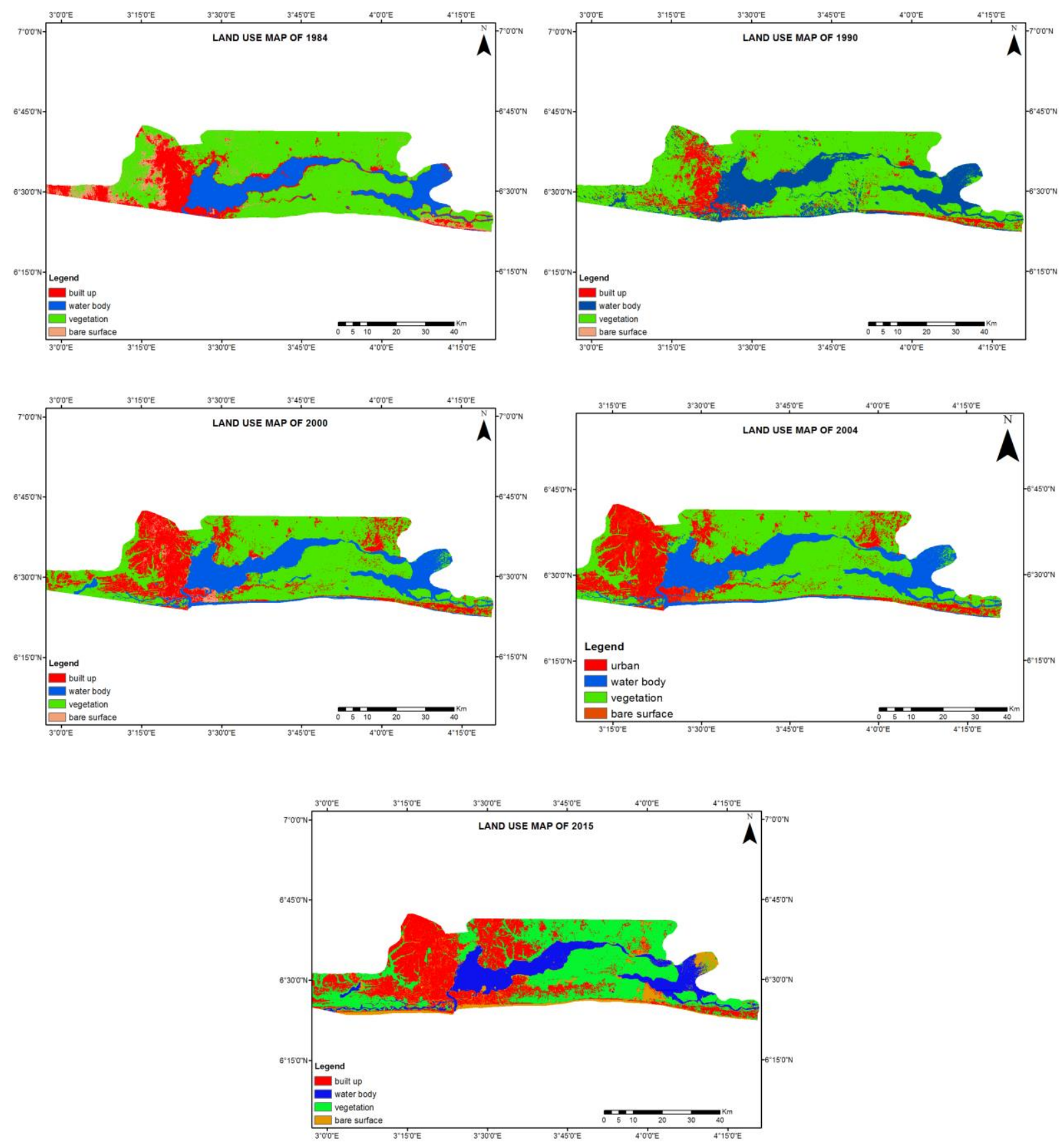

Fig.4. Land use/cover classification for 1984-2015 


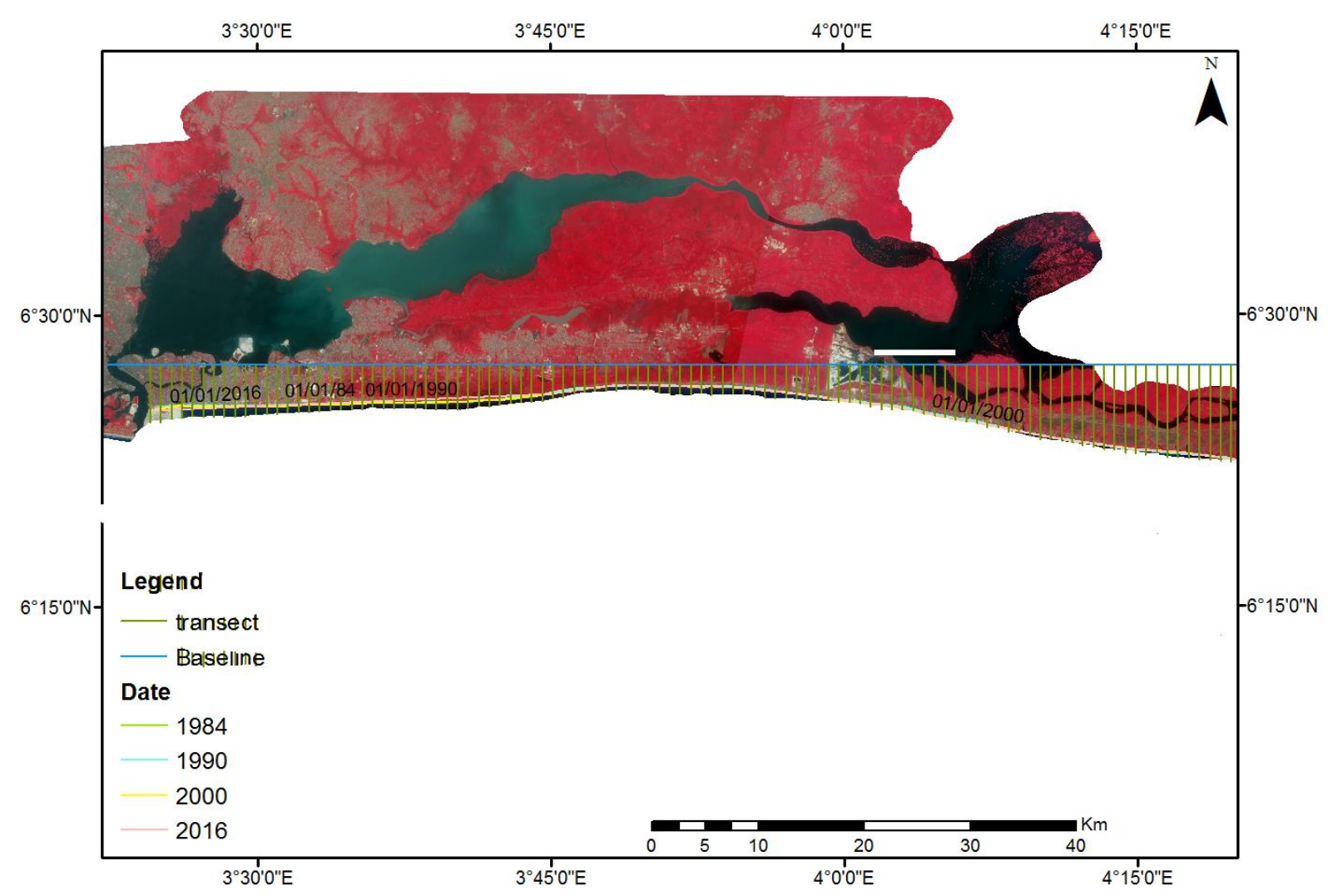

Fig.5. Digitized shorelines

The result of the analysis revealed changes in the Lagos shoreline, the net change measured as the distance between the most recent and earliest shorelines $(1984,1990,2000$, and 2016).The sum total of the magnitude of Net Erosion that occurred during the different periods under investigation is shown in Table 2.
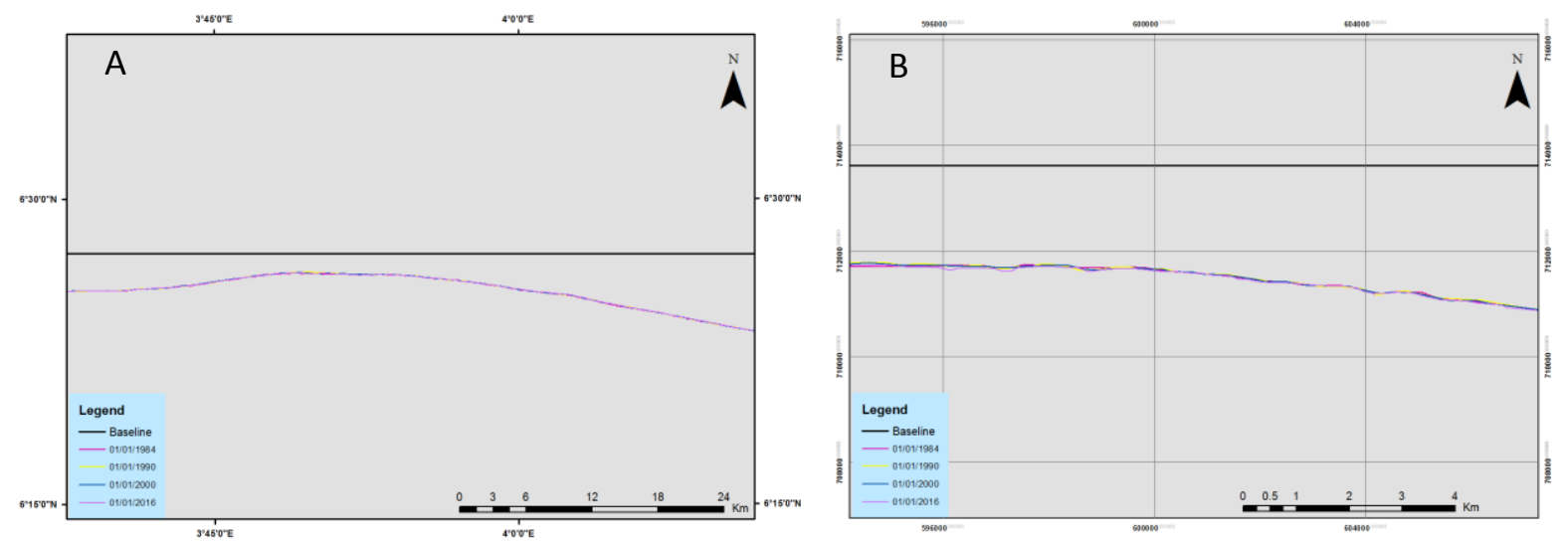

Fig.6. Extracted shorelines (A) and shoreline shift (B) 
both revealed that 231 transect or $22.3 \%$ experienced erosion, and 805 transect or $77.9 \%$ with accretion (Figures7 and 8). Based on the result of the shoreline erosion and accretion, itwas observed that accretion is more significant in most sections along the shoreline. Human activities along the coastline seems to have accelerated erosion processes during the period studied and also dominant accretion trend recorded might be attributed as a result of very shallow near-shore bathymetry, less wave current velocity and wave height along this areas. There is a close relationship consistent with the shoreline erosion and accretion (Table 3). It was observed that, while a very high erosion activity was recorded from 1984 to 1990, a very low accretion was recorded in that period. Likewise, erosional activity was high from 1990 to 2000 but accretion was recorded low in that period. In addition, erosional activity was recorded low from 2000 to 2016 but accretion was high in that same period (Table $3)$.
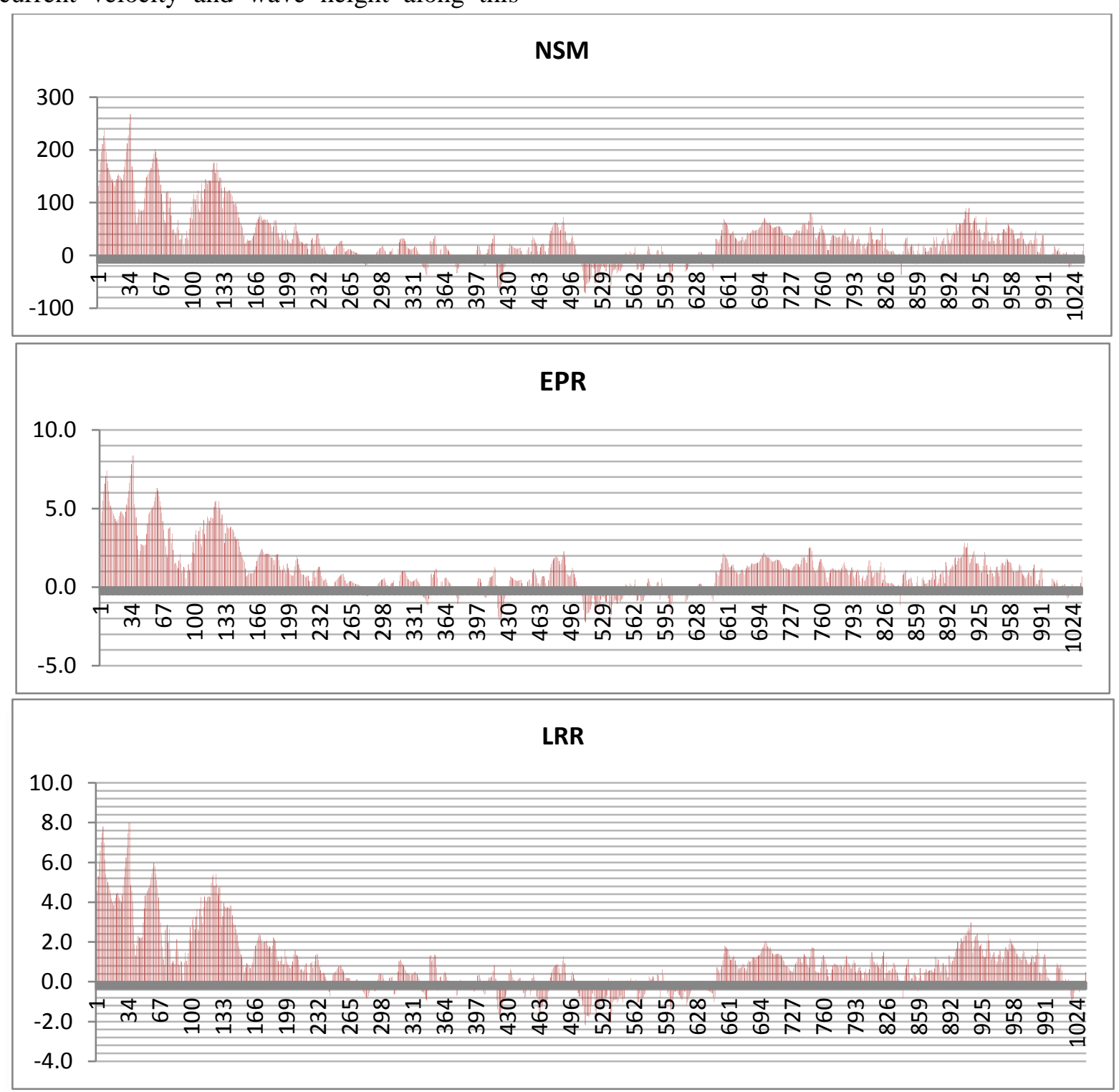

Fig.7. Graphs of shoreline changes 1984-2016, (a) End Point Rate (EPR), (b) Net Shoreline Movement (NSM), (c) Linear Regression Rate, (LRR). EPR and LRR are in m/year, while NSM is m/period. Most of the graph is in the positive area (i.e. below the line) which indicates shoreline accretion 
Tab.2: Overall shoreline change rates from 1984 to 2016

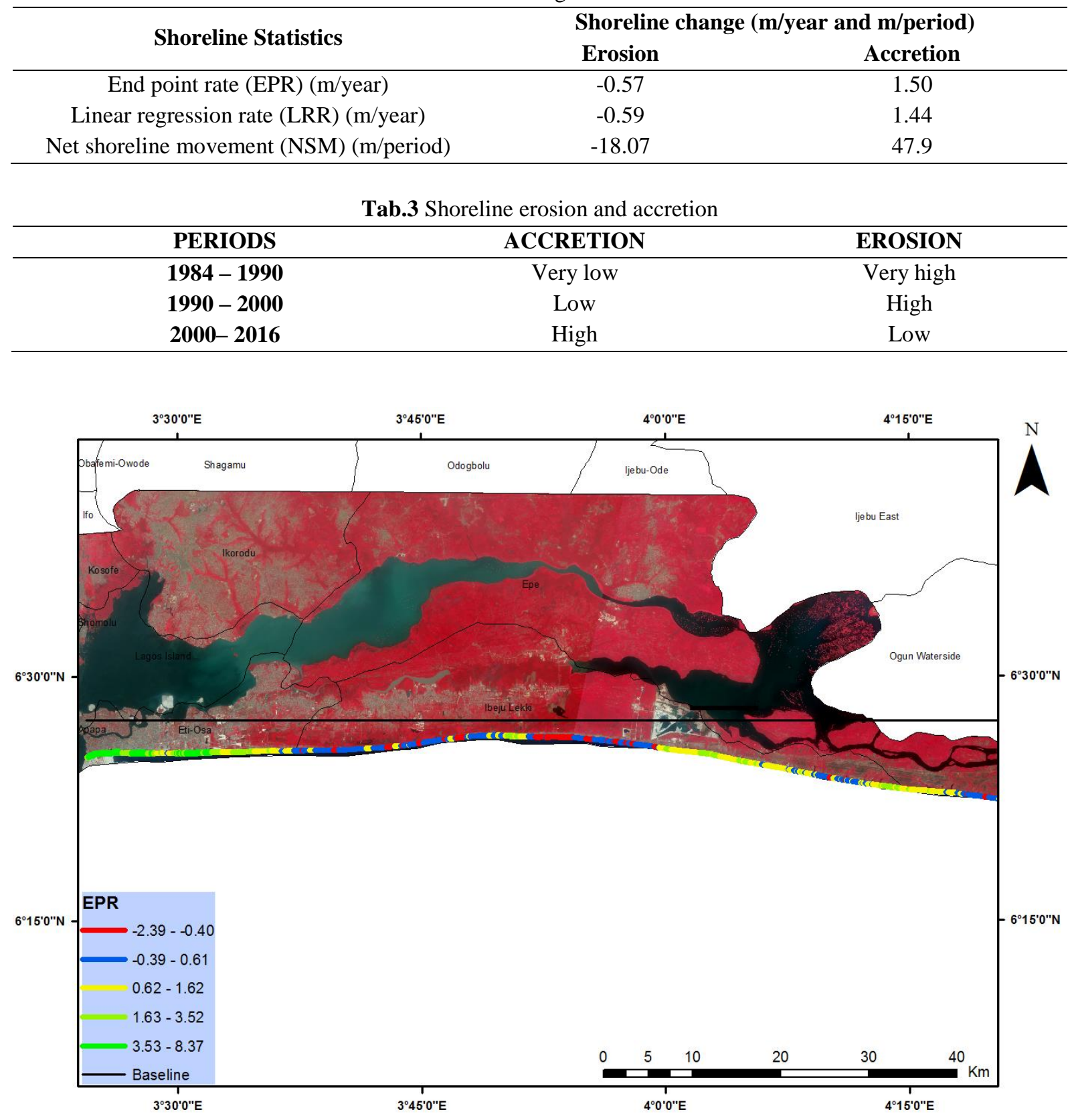

Fig.8: Rate of shoreline change (EPR m/year) along the shore from 1984-2016. (Negative values in red and blue colours indicate erosion whereas the positive values in green colours indicate accretion)

\section{Conclusion}

The study has demonstrated that the integration of satellite remote sensing and GIS based on LULC mapping is very effective for monitoring coastal LULC changes and also valuable for long term shoreline change studies with reasonable accuracy. In this study, it was observed based on findings that the Lagos coastline has experienced more accreting portions than eroding portions for all the periods. This can be attributed to beach 
nourishment activities that had taken place in the past especially along bar beach sections of the coastline (Awosika et al., 1991). Both natural and anthropogenic factors were observed to contribute to shoreline erosion and accretion. The destruction of vegetation along the coastline due to rapid urbanization and industrialization is observed to be responsible for shoreline erosion in some sections along the shorelines. The digital shoreline analysis system within the geographic information systems (GIS) proves useful in calculating longtime shoreline change which to a reasonable degree of accuracy has made the monitoring of shoreline changes due to erosion and/or accretion become practically possible. It is therefore recommended that proper land use management strategies should be put in place for areas in the coastal zone. Likewise, the stoppage of reclamation exercise along the coastal area and across Lagos lagoon should be addressed by relevant authorities. Similarly, adequate beach profiling survey should be carried out on a regular basis.

\section{References}

Ajayi, T.O and Adetayo. 1982. on the fish bycatch and discard of the shrimp fishery of Nigeria. Nig. Inst. Oceanogr. Mar. Res., Tech. pap. (5): 28p. Lagos, Nigeria

Appeaning, K, Addo, Walkden M, Mills, JP (2008) detection, measurement and prediction of shoreline recession in Accra, Ghana. ISSRS Journal of Photogrammetry and Remote sensing 63(5): 543-558

Awosika, L.F, Ibe , C.E, Adekoya , A., And Balogun, A. (1991). Monitoring of the 1990/91 Beach Replenishment Project at the Bar Beach, Lagos. A Progress Report for the Federal Ministry Of Works and Housing, Lagos.

Berlanga-Robles, C.A., J. Madrid-Vera and A. Ruiz-Luna, 2002.Fish abundance and trophic structure from the commercial catch in lake Patzcuaro, Mexico. Hydrobiologia 467:117-122.

Bird, E.C. (1993).Submerging Coasts: The Effects of a Rising Sea Level on Coastal Environments, Wiley, New York.

Boak, E.H. and Turner, I.L., 2005. Shoreline Definition and Detection: A Review. Journal of Coastal Research,21(4), 688703. West Palm Beach (Florida), ISSN 0749-0208.

Carter, R. W. G and Woodroffe, C.D. 1994. Eds: Coastal Evolution: Late Quarter Shoreline Morphodynamics. Cambridge University Press, Cambridge, UK.

Crowell, M.; Leatherman, S.P., and Buckley, M.K., 1993. Shore line change rate analysis: long term versus short term. Shore and Beach, 61(2), 13-20.

Government of Kenya (2010) (a). Shoreline Management Strategy for Kenya, National Environment Management Authority (NEMA), Nairobi. 87 pp.

Hanslow, D. J. (2007). Beach Erosion Trend Measurement: A Comparison of Trend Indicators, SI 50 Proceedings of the 9th International Coastal Symposium, 588 593. Journal of Coastal Research. Gold Coast, Australia, ISSN 0749.0208.

Hoorweg J. and Muthiga N.A. (2009).Advances in Coastal Ecology People, processes and ecosystems in Kenya.(African Studies Collection, vol. 20).2300 RB Leiden. African Studies Centre.

Kairu, K. and Nyandwi, N. (2000) Guidelines for the Study of Shoreline Change in the Western Indian Ocean Region IOC Manuals and Guides No. 40. UNESCO 2000.

Keqizhang, Bruce C. Douglas, and Stephen P. Leatherman. (2004). Global warming and Coastal

Erosion. Climatic Change 64: 41-58. Kluwer Academic Publishers. The Netherlands

Limber, P. W, List, J.H, Warren, J. D. (2007). Investigating Methods of Mean High Water Shorelines from Lidar Data and the Relationship between Photo-derived and 
Datum-based Shoreline in North Carolina. http://dcm3.enr.state.nc.us/.

Moore, L.J.; Benumof, B.T., and Griggs, G.B., 1999. Coastal erosion hazards in Santa Cruz and San Diego. Journal of Coastal Research, Special Issue No. 28, pp. 121-139.

Norman Kerle; Lucas L.F Janssen., and Wim H. Bakker. (2004): Principles of remote sensing: an introductory textbook. Ed: International institute for Geo-information Science and Earth Observation (ITC) pg. 103

Paterson, S.K. O'Donnell, A. Loomis, D.K. and Hom, P. (2010). The Social and Economic Effects of Shoreline Change: North Atlantic, South Atlantic, Gulf of Mexico, and Great Lakes Regional Overview. Human Dimensions of Natural Resource Management Research Unit Department of Natural Resources Conservation University of Massachusetts, Amherst, MA 01003.

Pearson, C.L., Manning, S.W., Coleman, M.L., Jarvis, K.E., 2005. Can tree-ring chemistry reveal absolute dates for past volcanic eruptions? Journal of Archaeological Science 32, 1265-1274.

Pidwirny M. (2006b). Fundamentals of physical geography. Chapter 10: Introduction to the
Lithosphere: Erosion and deposition. University of British Columbia, Okanagan. Richmond, B. M., (2012). National Assessment of Shoreline Change: Historical Change in the Hawaiian Island: U.S. Geological Survey Open-File Report 2011-1051, 55pp. (Available at http://pubs.usgs.gov/of/2011/1051).

WIOMSA (2010). Shoreline Change in Tanzania andKenya: Assessment Procedures and Mitigation Strategies for Management. WIOMSA Manuals No.00. Zanzibar.

Thieler, E. R. Himmelstoss, E. A. Zichichi, J. L. and Ayhan, E. (2009).Digital Shoreline Analysis System (DSAS) version 4.3. An ArcGIS extension for calculating shoreline change: U.S. Geological Survey Open-File Report 2008-1278. Available online at: http://pubs.usgs.gov/of/2008/1278

Williams, S.J. and Gutierrez, B.T. (2009). Sealevel rise and coastal change: Causes and implicationsfor the future of coasts and lowlying regions. U. S.Geological Survey Woods Hole Science Center.Shore \& Beach Vol. 77, No. 4.

http://earthexplorer.usgs.gov/ 